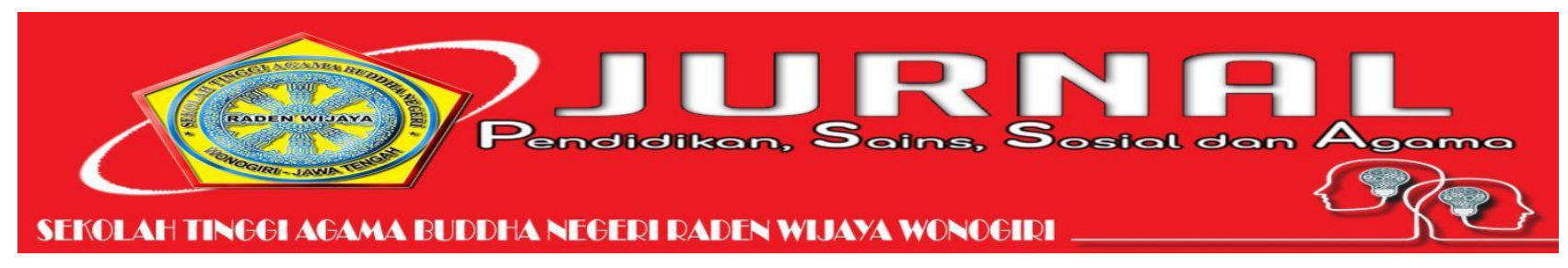

\title{
ANALISIS KESULITAN BELAJAR PADA MATA PELAJARAN MATEMATIKA DENGAN PEMBELAJARAN DALAM JARINGAN (DARING) SELAMA MASA DARURAT COVID-19 PADA SISWA KELAS VIII SMP NEGERI 2 NGADIROJO TAHUN AJARAN 2019/2020
}

\author{
Krisdianto Hadiprasetyo, Annisa Prima Exacta, Alyaa Maharani \\ Universitas Veteran Bangun Nusantara Sukoharjo \\ alyaamaharani25@gmail.com
}

\begin{abstract}
Abstrak
Penelitian ini bertujuan untuk mengetahui tingkat kesulitan belajar siswa kelas VIII SMP Negeri 2 Ngadirojo pada mata pelajaran matematika dengan pembelajaran dalam jaringan (daring) selama masa darurat covid-19 pada tahun ajaran 2019/2020. Penelitian yang dilakukan menggunakan penelitian deskriptif dengan pendekatan penelitian kualitatif. Subjek penelitian dalam penelitian ini adalah siswa kelas VIII E dan VIII G SMP Negeri 2 Ngadirojo sebagai populasi. Teknik pengumpulan data yang digunakan dalam penelitian ini adalah angket dan wawancara. Melalui penelitian ini diketahui bahwa tingkat kesulitan belajar siswa ada pada kategori cukup yakni antara 41,00-60,99\% dan kategori tinggi antara 21,00-40,99\%.pada kategori cukup dan tinggi.
\end{abstract}

Kata Kunci: kesulitan belajar, matematika, pembelajaran daring

Abstract
This study aims to determine the level of learning difficulty of grade VIII students of SMP Negeri 2 Ngadirojo in mathematics with online learning during the Covid-19 emergency period in the 2019/2020 academic year. The research was conducted using descriptive research with a qualitative research approach. The research subjects in this study were students of class VIII E and VIII G SMP Negeri 2 Ngadirojo as the population. The data collection techniques used in this study were questionnaires and interviews. Through this research it is known that the level of student learning difficulty is in the moderate category, namely between 41.00-60.99\% and the high category between 21.00-40.99\%. In the moderate and high categories.

Key Word: Learning Difficulties, Mathematic, Daring Learning 


\section{PENDAHULUAN}

Pada awal 2020, dunia dikejutkan dengan mewabahnya pneumonia baru yang bermula dari Wuhan, Provinsi Hubei yang kemudian menyebar dengan cepat ke lebih dari 190 negara dan teritori. Wabah ini diberi nama coronavirus disease 2019 (COVID-19) yang disebabkan oleh Severe Acute Respiratory Syndrome Coronavirus-2 (SARSCoV-2). COVID-19 pertama di Indonesia dilaporkan pada tanggal 2 Maret 2020 sejumlah 2 kasus (Santoso, Pitoyo, dkk, 2020: 45). Setelah masuk dan merebaknya virus COVID-19 di Indonesia, melalui keterangan pers pada tanggal 15 Maret 2020 Presiden Republik Indonesia, Joko Widodo meminta agar masyarakat Indonesia belajar, bekerja, dan beribadah dari rumah saja guna memutus rantai penyebaran virus COVID-19.

Salah satu sektor penting yang terkena dampak akan hal ini adalah bidang pendidikan. Mengacu pada Surat Mendikbud No.36962/MPK.A/HK/2020 mengenai kebijakan penyelenggaraan pendidikan selama masa pandemi COVID-19 yakni adanya alternatif pembelajaran dari rumah yang digunakan guru dengan siswa tanpa bertatap muka secara langsung. Akibatnya sekolah-sekolah mulai dari jenjang PAUD, TK, SD, SMP, SMA, hingga perguruan Tinggi baik negeri maupun swasta harus "merumahkan" siswanya untuk melakukan pembelajaran jarak jauh. Dalam hal ini, pembelajaran jarak jauh yang dimaksud sesuai dengan Permendikbud No. 109 Tahun 2013 adalah proses belajar mengajar yang dilakukan secara jarak jauh melalui penggunaan berbagai media komunikasi. Media komunikasi yang digunakan dalam pembelajaran jarak jauh saat ini adalah aplikasi dalam jaringan (daring) sehingga kini disebut dengan pembelajaran dalam jaringan (daring).

Salah satu sekolah yang menerapkan pembelajaran daring di masa darurat COVID19 adalah SMP Negeri 2 Ngadirojo. Menurut keterangan dari salah satu siswa kelas VIII, pelaksanaan pembelajaran daring dimulai sejak tanggal 13 Maret 2020 hingga saat ini. Pembelajaran daring yang dilaksanakan mencakup seluruh mata pelajaran yang diajarkan di sekolah, termasuk Matematika. Matematika memiliki peranan penting dalam upaya penguasaan ilmu pengetahuan dan teknologi (Rachmayani, 2014: 14). Salah satu ciri penting matematika adalah memiliki objek abstrak, sehingga kebanyakan siswa menganggap matematika itu sulit (Murwaningsih dan Astutiningtyas, 2013: 205). Menurut Exacta dan Farahsanti (2016: 48-49) di kalangan siswa, matematika dianggap sebagai momok yang menakutkan karena menurut mereka materinya sulit untuk dipahami. Hal ini sejalan dengan yang disampaikan oleh salah satu guru matematika di SMP Negeri 2 Ngadirojo bahwa sebagian besar siswa menganggap matematika adalah salah satu mata pelajaran yang dianggap sulit. Selain itu, dari beberapa siswa kelas VIII diketahui bahwa matematika termasuk pelajaran yang mereka anggap sulit dan tidak disukai. Karena hal ini pula, akhirnya siswa mengalami kesulitan belajar matematika. Dalam kondisi seperti saat ini, dengan pembelajaran daring, beberapa siswa mengatakan bahwa kesulitan belajar matematika juga terjadi. Jika menemukan kesulitan, dalam pembelajaran di sekolah, siswa dapat langsung bertanya pada guru. Namun, melalui pembelajaran daring saat ini siswa dituntut untuk dapat menemukan solusi dari kesulitan tersebut secara mandiri. Meskipun siswa memiliki akses untuk bertanya kepada bapak/ibu guru melalui daring, tetapi tidak selalu memperoleh jawaban yang jelas dan justru diminta untuk mencari di internet. Berdasarkan uraian yang telah dikemukakan di atas maka akan dilakukan suatu analisis kesulitan belajar pada mata pelajaran matematika dengan pembelajaran daring selama masa darurat Covid-19 pada siswa kelas VIII SMP Negeri 2 Ngadirojo.

Coronavirus Disease 2019 (COVID19) adalah penyakit saluran napas yang disebabkan oleh virus corona jenis baru yang belum pernah diidentifikasi sebelumnya pada manusia. COVID-19 pertama kali ditemukan di Wuhan, China pada akhir tahun 2019 dan dikenal dengan nama Novel Corona Virus 2019 atau SARS Coronavirus 2 (Kementerian Kesehatan Republik Indonesia, 6: 2020). 
Menurut Surat Keputusan Badan Nasional Penanggulangan Bencana Nomor 9 A Tahun 2020 dalam rangka mengantisipasi menyebarnya virus corona di wilayah Negara Kesatuan Republik Indonesia, diperlukan penanganan darurat bencana yang dilaksanakan berdasarkan status keadaan darurat maka ditetapkan status keadaan darurat bencana wabah penyakit akibat virus corona di Indonesia yang berlaku selama 32 (tigapuluh dua) hari terhitung sejak tanggal 28 Januari 2020 sampai dengan tanggal 28 Februari 2020.

Kemudian, dengan menimbang bahwa penyebaran virus corona semakin meluas dan menyebabkan jatuhnya banyak korban jiwa, kerugian harta benda, dampak psikologis pada masyarakat, serta mengancam dan mengganggu kehidupan dan penghidupan masyarakat maka berdasarkan Surat Keputusan Kepala Badan Nasional Penanggulangan Bencana Nasional Republik Indonesia Nomor 11 Tahun 2020 dilakukan perpanjangan status keadaan tertentu darurat bencana wabah penyakit akibat virus corona di Indonesia yang berlaku selama 91 (sembilan puluh satu hari), terhitung sejak tanggal 29 Februari sampai tanggal 29 Mei 2020. Oleh karena itu, merujuk pada status masa darurat covid-19 di Indonesia, maka diberlakukan pembelajaran dalam jaringan (daring) agar pelaksanaan pembelajaran dapat terus dilakukan. Pembelajaran daring adalah salah satu metode pembelajaran online atau dilakukan melalui jaringan internet. Sistem ini dikembangkan oleh Kementerian Pendidikan dan Kebudayaan Republik Indonesia. Tujuan dari diadakannya pembelajaran daring menurut Kementerian Pendidikan dan Kebudayaan Republik Indonesia (2014: 15) adalah sebagai berikut :

1) Meningkatkan ketersediaan layanan pendidikan

2) Meningkatkan keterjangkauan layanan pendidikan

3) Meningkatkan kesamaan dalam mendapatkan layanan pendidikan.

Namun, di dalam pelaksanaan pembelajaran daring ini juga terdapat beberapa kekurangan, antara lain :
1) Siswa yang tidak memiliki motivasi belajar yang tinggi cenderung gagal

2) Terjadinya kesalahpahaman antar guru dan siswa mengenai materi belajar

3) Akses internet yang sulit di beberapa tempat

Kesulitan belajar adalah ketidakmampuan siswa dalam memahami konsep, prinsip, dan keterampilan karena mengalami hambatan atau kendala baik internal maupun eksternal dalam proses belajarnya sehingga siswa tidak dapat melakukan proses belajar secara maksimal. Berdasarkan uraian sebelumnya mengenai kesulitan belajar, terdapat faktor internal dan faktor eksternal yang menjadi penyebab terjadinya kesulitan belajar. kesulitan belajar matematika adalah ketidakmampuan siswa dalam memahami konsep, prinsip, dan keterampilan karena mengalami hambatan atau kendala baik internal maupun eksternal dalam proses belajar matematika.

Menurut Aryani (2017: 24-25) faktor internal dan faktor eksternal penyebab kesulitan belajar adalah sebagai berikut:

1) Faktor Internal

Faktor Internal yaitu faktor yang berasal dalam diri siswa yang menyebabkan kesulitan belajar. Faktor internal penyebab kesulitan belajar antara lain sebagai berikut:

a) Sikap terhadap belajar yang meliputi kesiapan dan kesungguhan mengikuti pelajaran,

b) Motivasi belajar yang meliputi semangat dalam mengikuti pelajaran,

c) Minat belajar yang meliputi perhatian dan rasa senang siswa dalam mengikuti pelajaran, serta

d) Kesehatan yang meliputi kondisi fisik (fisiologis) peserta didik.

2) Faktor Eksternal

Faktor eksternal yaitu faktor dari luar diri siswa yang menyebabkan siswa kesulitan belajar. Adapun faktor eksternal penyebab kesulitan belajar antara lain sebagai berikut :

a) Lingkungan keluarga yang meliputi perhatian orangtua, ekonomi keluarga dan suasana di rumah,

b) Lingkungan sekolah yang meliputi metode mengajar, relasi siswa, media 
pembelajaran yang digunakan, dan waktu pembelajaran,

c) Lingkungan masyarakat yang meliputi kegiatan siswa di masyarakat, teman bergaul, dan media massa yang berpengaruh terhadap siswa sehingga mengganggu proses belajarnya.

Sedangkan menurut Hamalik (dalam Hanik, 2015: 17) faktor internal adalah faktor yang muncul dari dalam diri siswa dan faktor eksternal adalah faktor yang berasal dari luar siswa.

1) Faktor Internal

a) Tidak memiliki tujuan belajar yang jelas,

b) Kurangnya minat terhadap pelajaran,

c) Kesehatan yang terganggu dan kurangnya penguasaanterhadap bahasa

2) Faktor Eksternal

a) Faktor keluarga yaitu tentang bagaimana cara mendidik anak, hubungan anak dengan orang tua, suasana keluarga, dan faktor ekonomi keluarga, dan kurangnya pengawasan orang tua

b) Faktor lingkungan sekolah misalnya metode dalam pembelajaran, bahan pelajaran yang tidak sesuai, dan waktu penyelenggaraan pembelajaran,

c) Faktor dari lingkungan masyarakat yang meliputi siswa yang aktif berorganisasi, tidak mempunyai teman belajar bersama.

\section{METODE}

Metode penelitian yang digunakan dalam penelitian ini adalah penelitian deskriptif dengan pendekatan penelitian kualitatif. Jenis penelitian ini akan digunakan untuk mendeskripsikan dan menggambarkan hasil analisis kesulitan belajar matematika pada pembelajaran daring selama masa darurat Covid-19 pada siswa kelas VIII SMP Negeri 2 Ngadirojo. Sedangkan subyek dalam penelitian ini adalah siswa kelas VIII $G$ dan VIII E SMP Negeri 2 Ngadirojo sebagai populasi. Kemudian, lebih lanjut melalui tahapan reduksi data menggunakan purposive sampling yakni teknik penentuan sampel dengan pertimbangan tertentu (Sugiyono, 2015: 124). Pertimbangan yang digunakan untuk purposive sampling dalam penelitian ini adalah hasil angket siswa yang mengalami kesulitan belajar dengan indikator sangat tinggi, tinggi, dan cukup. Adapun tingkat kategori dan persentase kesulitan belajar siswa ditunjukkan dalam tabel berikut ini :

Tabel 1

Kriteria Tingkat Kesulitan Belajar

\begin{tabular}{|c|c|}
\hline Persentase Skor & Kategori \\
\hline $81,00 \% \leq \mathrm{P} \leq 100 \%$ & $\begin{array}{l}\text { Sangat } \\
\text { Rendah }\end{array}$ \\
\hline $\begin{array}{l}61,00 \% \leq \mathrm{P} \leq \\
80,99 \%\end{array}$ & Rendah \\
\hline $\begin{array}{l}41,00 \% \leq \mathrm{P} \leq \\
60,99 \%\end{array}$ & Cukup \\
\hline $\begin{array}{l}21,00 \% \leq \mathrm{P} \leq \\
40,99 \%\end{array}$ & Tinggi \\
\hline $0,00 \% \leq \mathrm{P} \leq 20,99 \%$ & $\begin{array}{l}\text { Sangat } \\
\text { Tinggi }\end{array}$ \\
\hline
\end{tabular}

(Wahyudi, 2015: 22)

Teknik pengumpulan data yang digunakan dalam penelitian ini adalah teknik angket dan teknik wawancara. Menurut Arifin (2011: 228) angket adalah instrumen penelitian yang berisi serangkaian pertanyaan atau pernyataan untuk menjaring informasi yang harus dijawab responden secara bebas sesuai dengan pendapatnya. Teknik ini bertujuan guna memperoleh data yang berkaitan dengan tingkat kategori kesulitan belajar matematika dengan pembelajaran daring selama masa darurat Covid-19 siswa kelas VIII SMP Negeri 2 Ngadirojo.Angket yang digunakan dalam penelitian ini adalah angket tertutup berupa daftar check-list. Angket tertutup adalah angket yang telah disediakan jawabannya sehingga responden tinggal memilih (Arikunto, 2013: 195). Untuk memilih jawaban yang sesuai, responden harus membubuhkan tanda check list pada kolom pilihan jawaban yang telah disediakan. Berdasarkan hasil angket yang diperoleh oleh masing-masing siswa, nantinya akan diketahui siswa dengan kategori tingkat kesulitan sangat tinggi, tinggi dan cukup yang akan dijadikan subyek wawancara guna penelitian lebih lanjut. 
Kemudian, teknik wawancara dalam penelitian ini dipakai sebagai teknik pengumpulan data apabila peneliti ingin melakukan studi pendahuluan untuk menemukan permasalahan yang harus diteliti dan juga apabila peneliti ingin mengetahui hal-hal yang bersifat mendalam dari responden (Sugiyono, 2015: 194). Perangkat pedoman wawancara yang akan digunakan bersifat terbuka yang dalam penelitian ini diharapkan dapat memperoleh data berupa kesulitan belajar matematika dengan pembelajaran daring selama masa darurat Covid-19 pada siswa kelas VIII SMP Negeri 2 Ngadirojo.

\section{HASIL}

\section{Hasil Penelitian}

Penelitian ini dilaksanakan di SMP Negeri 2 Ngadirojo. SMP Negeri 2 Ngadirojo beralamat di Jalan Ngadirojo-Jatipuro Km. 2, Kecamatan Ngadirojo, Kabupaten Wonogiri Kode Pos 57681 dengan Nomor Statistik Sekolah yaitu 204031213103 dan nilai akreditasi sekolah A. Subjek penelitian dalam penelitian ini adalah siswa kelas VIII G sejumlah 27 siswa dan VIII E sejumlah 28 siswa dengan total 55 siswa sebagai populasi. Angket kesulitan belajar dalam penelitian ini bertujuan untuk mengetahui tingkat kesulitan belajar siswa dalam mata pelajaran matematika melalui pembelajaran daring. Angket yang digunakan dalam penelitian ini adalah angket tertutup dengan skala Likert dengan 4 pilihan jawaban untuk pernyataan positif maupun negatif. Angket kesulitan belajar matematika yang digunakan telah divalidasi oleh Ibu Sugiyarni, S.Pd. selaku validator untuk kemudian dibagikan kepada siswa secara online dalam bentuk Google Form pada tanggal 14-17 Juli 2020 melalui WhatsApp Group kelas $8 \mathrm{E}$ dan $8 \mathrm{G}$ dan telah diisi oleh 55 siswa. Berdasarkan analisis angket kesulitan belajar matematika dari seluruh siswa yang menjadi responden, diperoleh hasil sebagai berikut :

a. 7 orang siswa mengalami tingkat kesulitan belajar matematika kategori cukup, b. 3 orang siswa mengalami tingkat kesulitan belajar matematika kategori ,

c. Tidak ditemukan adanya siswa yang mengalami tingkat kesulitan sangat tinggi.

Rincian persentase tingkat kesulitan belajar dari tiap-tiap siswa di atas ditunjukkan pada tabel 3 berikut ini :

Tabel 3 Hasil Analisis Angket Kesulitan Belajar

\begin{tabular}{|c|c|c|}
\hline No & $\begin{array}{c}\text { Persentase } \\
\text { Kesulitan Belajar } \\
(\%)\end{array}$ & Kategori \\
\hline 10 & 54,34782606 & Cukup \\
\hline 20 & 59,7826087 & Cukup \\
\hline 36 & 57,60869565 & Cukup \\
\hline 40 & 59,7826087 & Cukup \\
\hline 41 & 52,173913043 & Cukup \\
\hline 42 & 46,73913043 & Cukup \\
\hline 43 & 39,13043478 & Tinggi \\
\hline 45 & 48,91304348 & Cukup \\
\hline 46 & 34,7826087 & Tinggi \\
\hline 47 & 33,69565217 & Tinggi \\
\hline
\end{tabular}

Berdasarkan hasil yang ditunjukkan pada tabel di atas, dapat digunakan untuk menentukan subyek yang akan diwawancara lebih lanjut. Subyek yang terpilih adalah semua responden yang ditunjukkan pada tabel di atas karena memenuhi kriteria siswa dengan persentase tingkat kesulitan belajar cukup dan tinggi. Pada responden nomor 20 dan 40 terdapat kesamaan tingkat persentase tingkat kesulitan belajar yakni sebesar $59,7826087 \%$ dan masuk ke dalam kategori cukup. Namun, setelah hasil angket dari keduanya di analisis terdapat beberapa perbedaan sehingga keduanya ikut dijadikan subyek wawancara.

Kemudian berdasarkan hasil analisis angket, maka dilakukan wawancara kepada subyek terpilih. Hasil wawancara dengan subyek terpilih adalah sebagai berikut:

a. 5 dari 10 siswa tidak menyukai pembelajaran matematika secara daring dan lebih menyukai pelajaran matematika secara langsung.

b. Seluruh siswa mengikuti pembelajaran matematika secara daring dalam keadaan sehat. 
c. 6 dari 10 siswa menjawab bahwa matematika adalah mata pelajaran yang sulit dipelajari dengan pembelajaran daring. Sedangkan sisanya menjawab matematika tidak sulit dipelajari meskipun melalui pembelajaran daring.

d. 6 dari 10 siswa tidak mempelajari materi matematika sebelum pembelajaran dimulai.

e. Media yang digunakan oleh guru dalam proses pembelajaran matematika dengan daring adalah WhatsApp Group dan Google Form.

f. Tidak ada sanksi yang diberikan guru jika siswa tidak mengumpulkan tugas secara tepat waktu.

g. Siswa tidak mengikuti bimbingan belajar matematika online melalui aplikasi.

\section{Pembahasan}

Berdasarkan uraian hasil penelitian menunjukkan bahwa kesulitan belajar siswa kelas VIII SMP Negeri 2 Ngadirojo pada mata pelajaran matematika dengan sistem daring ditinjau dari beberapa indikator yaitu :

1. Kesediaan atau mengikuti pelajaran,

2. Kemampuan pemahaman materi dalam belajar,

3. Kemampuan menyelesaikan tugas dan soal latihan secara tepat waktu,

4. Ketersediaan media dan sumber belajar yang diperlukan,

5. Pengaturan waktu dan suasana belajar,

6. Kemampuan menjalin komunikasi dengan teman diskusi atau teman belajar,

7. Pemanfaatan teknologi, media massa, aplikasi belajar dan internet,

Dari masing-masing indikator di atas diketahui bahwa tingkat kesulitan belajar yang dialami siswa kelas VIII SMP Negeri 2 Ngadirojo pada pelajaran matematika dengan pembelajaran daring memiliki kategori cukup dan tinggi.

Pada kategori cukup, tingkat persentase kesulitan belajar siswa ada pada interval 41,00 - 60,99\%. Berdasarkan hasil wawancara dari siswa dengan tingkat kesulitan belajar yang cukup, siswa kurang antusias mengikuti pembelajaran daring karena lebih menyukai pembelajaran langsung, siswa tetap mempersiapkan diri sebelum mengikuti pembelajaran daring dan memiliki catatan serta buku pendamping matematika yang diperlukan dalam belajar. Selain itu, penjelasan yang diberikan oleh guru membantu siswa dalam memahami materi yang dipelajari. Jika mengalami kesulitan siswa juga dapat dengan mudah bertanya kepada teman atau guru sehingga mendapat penjelasan yang membantu. Pada kategori tinggi, tingkat persentase kesulitan belajar siswa ada pada interval 21,00 $40,99 \%$. Berdasarkan hasil wawancara siswa yang memiliki tingkat kesulitan belajar tinggi disebabkan karena tidak menyukai pelajaran matematika karena menganggap matematika adalah pelajaran yang sulit sehingga menyebabkan siswa tidak antusias dalam mengikuti pelajaran dan siswa tidak mempersiapkan diri sebelum mengikuti pelajaran. Hal ini sejalan dengan Prabandari (2019: 6) bahwa siswa yang tidak menyukai matematika karena matematika dianggap mata pelajaran yang sulit sehingga siswa tidak antusias dalam mengikuti pelajaran. Selain itu, berdasarkan hasil wawancara, siswa dengan tingkat kesulitan belajar kategori tinggi tidak memiliki kelengkapan alat, catatan materi dan buku pendamping belajar serta koneksi internet yang kurang baik untuk mengikuti pembelajaran daring.

\section{Kesimpulan}

Berdasarkan analisis data dan pembahasan dari hasil penelitian dapat ditarik kesimpulan bahwa kesulitan belajar matematika siswa dengan pembelajaran daring ada pada kategori cukup dan tinggi dengan rincian 7 orang siswa kelas VIII dengan tingkat kesulitan belajar kategori cukup dan 3 orang siswa dengan tingkat kesulitan belajar kategori tinggi. Kemudian dari hasil wawancara, diketahui bahwa siswa tidak antusias dalam mengikuti pembelajaran daring pada mata pelajaran matematika dan lebih suka melakukan pembelajaran langsung. Selain itu, koneksi internet yang dimiliki siswa kurang mendukung selama proses pembelajaran daring matematika berlangsung. 


\section{Daftar Pustaka}

Arifin, Z. 2011. Penelitian Pendidikan. Bandung: PT Remaja Rosdakarya

Arikunto, Suharsimi. 2013. Prosedur Penelitian. Jakarta: Rineka Cipta

Aryani, Farida. 2017. Faktor-Faktor Penyebab Kesulitan Belajar Dalam Mengikuti Mata Pelajaran Pembuatan Pola Siswa Kelas X SMK Muhammadiyah 1 Tempel. Skripsi. Program Studi Pendidikan Teknik Busana Fakultas Teknik Universitas Negeri Yogyakarta.

Astutiningtyas, Erika Laras, Murwaningsih, Utami. 2013. Implementasi Pengembangan Perangkat Pembelajaran Matematika Realistik di Sekolah Menengah Pertama. Prosiding SNMPM Universitas Sebelas Maret 2013 Volume 1: 205282.

Direktorat Kesehatan Keluarga. 2020. Panduan Pelayanan Kesehatan Balita Pada Masa Tanggap Darurat Covid 19 Bagi Tenaga Kesehatan. Jakarta: Kementerian Kesehatan Republik Indonesia.

Exacta, Prima, A., Farahsanti, Isna. 2016. Pendekatan Pembelajaran Metakognitif Dengan Media Flash Swishmax Pada Pembelajaran Matematika SMP. Jurnal Pendidikan Dan Pembelajaran Matematika (Jp2m) Vol. 2 No.2: 48-56.

Hanik, Noor Asti. 2015. Faktor-Faktor Penyebab Kesulitan Belajar Pengolahan Makanan Kontinental Siswa Kelas XI di Sekolah Menengah Kejuruan Negeri 3 Wonosari. Skripsi. Program Studi Pendidikan Teknik Boga Fakultas Teknik Universitas Negeri Yogyakarta.
Santoso, Djoko Widayat, Pitoyo Ceva, W., Susilo A., dkk. 2020. Coronavirus Disease 2019: Tinjauan Literatur Terkini. Jurnal Penyakit Dalam Indonesia Vol. 7 No. 1 : 45-67.

Sugiyono. 2015. Metode Penelitian Pendidikan. Bandung: Alfabeta.

Surat Keputusan Badan Nasional Penanggulangan Bencana Nomor 9 A Tahun 2020.

Surat Keputusan Kepala Badan Nasional Penanggulangan Bencana Nasional Republik Indonesia Nomor 11 Tahun 2020.

Permendikbud No. 109 Tahun 2013 